\title{
Shared Symbols
}

\section{Muslims, Marian Pilgrimages and Gender}

\author{
Willy Jansen \\ RADBOUD UNIVERSITY NIJMEGEN
}

\section{Meike Kühl}

UTRECHT UNIVERSITY

ABSTRACT Despite the trend of secularization, pilgrimages to sacred sites flourish. Most of the pilgrims are women and the reasons for their visits often have to do with the dynamics of women's lives. Some of the pilgrims to sites dedicated to St Mary are Muslims. This is interesting in the present political context in which lines are being redrawn between Christians and Muslims and their respective religious identities. Why would Muslims go to Marian shrines and how do they negotiate their relationship to the figure of the Virgin Mary and thereby define their gender and religious position? This article describes the experiences of Muslim pilgrims at Marian sites in Germany, Portugal and Turkey, and analyses these in terms of gender and religious identity.

KEY WORDS Europe $\bullet$ gender $\bullet$ Mary $\bullet$ Muslim $\bullet$ pilgrimage $\bullet$ shared religious practices

\section{INTRODUCTION}

Despite Catholic churches in Western Europe seeing sharp falls in attendances, millions of pilgrims continue to visit religious shrines each year. Several scholars have noted a growth in the popularity of pilgrimage in recent decades (Coleman and Eade, 2004; Eade and Sallnow, 1991; Reader, 2007). Making pilgrimages to sacred sites, in particular to Mecca, is also common in Islam (Jansen and de Jonge, 1991; Reysoo, 1991). In both religions, popular forms of religious expression exist in which people visit sites devoted to saints, who are seen as mediators between them and God, to ask for blessings and support. Pilgrims fol-

European Journal of Women's Studies Copyright (C) 2008 SAGE Publications (Los Angeles, London, New Delhi and Singapore), 1350-5068 Vol. 15(3): 295-311; http:/ / ejw.sagepub.com DOI: 10.1177/1350506808091509 
low similar rituals of praying, burning candles, making offerings or collecting holy water for personal use. Such religious practices have regularly been condemned by religious officials as 'folk religion', 'superstition' or 'idolatry'. Basic critiques are directed at the adoration of persons other than God and at the visualization and representation of the holy as embodied in material devotional objects. At certain historical moments, however, popes and clergy or Muslim leaders have also recognized or supported such practices.

The rejection of popular forms of religious observance has a strong gendered dimension, as it is mostly women who partake in the activities discouraged by the Church and the Islamic scripturalists, and therefore women's religious practices that are deprecated. Tapper reported how men in the Turkish town she studied viewed the visits of women to saintly shrines 'as verging on heresy' (Tapper, 1990: 247). Women, by contrast, give different interpretations of their behaviour and resist the dominant, male-controlled, interpretation of what constitutes a proper religious act. Other scholars too have noted that pilgrimage should be seen as a gendered practice. In general, more women than men visit religious shrines (Dubisch, 1995). The 'saint' they visit is also more often than not a woman rather than a man. In Europe, Mary and other female saints are three times more often the primary subjects of devotion than Christ or male saints (Nolan and Nolan, 1983: 428). Further, a strong presence of female religious themes and forms of expression has been observed (Gemzöe, 2000). Feminist scholars have argued that Marian devotion and pilgrimage can both reinforce dominant gender patterns, by upholding ideals of femininity, and also provide opportunities for women to improve their power position and to change structural gender inequalities (Rodriguez, 1994; Warner, 1978). It is therefore important to understand how gender is enacted and changed during such religious observances.

The vitality of this form of religious observance intersects with other social forces at play in present-day Europe. Expansion of the European Union is changing the Christian landscape. Immigrants have introduced new churches and religious vibrancy. The presence of Islam has also become noticeable, due to the growth of the Muslim population, and also to the discussions on the integration of Turkey into the EU and to acts of Islamist terrorism. This has led to a renewed religious vigour. The Virgin Mary has historically been an important symbol in expressing antagonism between Christians and Muslims in Europe. During the Spanish Reconquista, the Catholics fought under the banner of Mary against the Moors, the memory of which is kept alive today by ritual replays of these battles and commemorative Marian statues in several Spanish towns. But Marian devotion can also be a uniting rather than a dividing force. There seems to be a continuing Muslim interest in Mary, exemplified by 
Muslims who visit Marian pilgrimage sites (Albera, 2005; Duijzings, 1991; Jansen, 2005), or Muslims who see in Mary a commonality between the two religions (Schleifer, 1997). Recently, academics have started to study the sharing of shrines in the Middle East, North Africa and the Balkans, ${ }^{1}$ and we hope to add with this research more data on European sites. ${ }^{2}$ In this article, the focus is on which Muslims visit Marian shrines, and why, and on the ways in which this can be seen as a gendered practice. How do Muslim pilgrims to Marian shrines negotiate their relationship to the figure of the Virgin Mary and thereby define their gender and religious position?

We analyse the experiences of Muslim pilgrims to Marian pilgrimage sites in Germany, Portugal and Turkey, in order to provide insights into the meanings of Mary they share with Christians and to consider to what extent this practice can be seen as liberating or empowering in gender terms. We aim to demonstrate that the practical flexibility exhibited in religious behaviour at shared shrines complicates and challenges the dominant discourses of mutual incompatibility and irredeemable opposition between religions and genders.

\section{METHODOLOGY}

This article is based on a study of the relevant literature and three short anthropological fieldwork studies carried out in Kevelaer (Germany), Fátima (Portugal) and Selçuk (Turkey) in the spring of 2007. The sites were selected because of their differences in the degree to which Muslims could be expected to visit them. Kevelaer has no known history of being attractive to Muslims, Fátima carries the name of the daughter of the Prophet Muhammad and might therefore be expected to be of interest for Muslims, and Selçuk as a Christian site surrounded by a Muslim population might also be a potential candidate for shared pilgrimages. It was not easy to identify the few Muslims among the large crowds of Christian pilgrims during the short time available but some were found by systematically asking about religious background. All the Muslims identified were interviewed as extensively as possible. Pseudonyms were used to respect their privacy. Moreover, formal and informal interviews were held with other visitors and personnel involved with the sites. Following Coleman and Elsner (2002), we focused on the perceptions of the respondents, their narratives, ritual practices and devotional objects, in short on 'lived religion' rather than on theological doctrine. This enabled us to identify some reasons why Muslims visit Marian shrines, and how both Muslims and Christians perceive such religious behaviour. Inspired by Eade and Sallnow (1991), who showed pilgrimage sites to be places where the sacred was contested, we wanted first to give space to the individual and 
often dissonant voices about the sacred and, second, to show how this contestation of the sacred was related to gender.

\section{PLACES AND PILGRIM PROFILES}

\section{Kevelaer}

The Marian site in Kevelaer, Germany, has drawn pilgrims since Hendrik Busman and his wife had visions of Mary and built a chapel in 1642. The main devotional object is a copperplate print with an image of Mary as the Consoler of the Afflicted. About 800,000 pilgrims visit Kevelaer annually. ${ }^{3}$ Among those who regularly go on pilgrimage to Kevelaer are the inhabitants of a shelter for battered women in another German town. Meike Kühl interviewed six of these women with Christian, Buddhist and Muslim backgrounds in order to understand how Marian devotion helped them to deal with their complex lives involving domestic violence (Kühl, 2007).

One of the Muslim women was Mariella, a 22-year-old Roma woman. Mariella considered Mary as her great help in crisis, or as she formulated it, 'she has led me out of the fire'. She related how her mother, a Muslim, also regularly visited Catholic churches in order to pray to Mary. Mary, according to Mariella, helped people who prayed to her daily and who believed in her. She evaluated Mary as being a very important saint in Islam and she preferred her above praying to God as she perceived him as masculine and patriarchal. Mary had helped her to run away from home three years earlier. She then went to live with her lover but after she had become pregnant, he started to abuse her mentally, physically and sexually and locked her in their home. When Kühl asked her how Mary could have wanted her to end up in such a hell, she said: 'That's because I prayed so much. I wanted it so badly. Love is blind, isn't it?' Clearly, Mariella did not hold Mary responsible for the outcome of her interventions: Mary had helped her to make her own choice, and it was not Mary's fault that it was a bad one.

Locked in her house, Mary was the only person Mariella could go to with her problems. Mary supported her; Mariella heard her say in her head: 'Keep courage. You can make it.' One evening Mariella prayed very intensely and yearned for freedom. The next afternoon, when her partner left the house, Mariella managed to escape through a secondfloor window. She believed that it was Mary who arranged for her husband to forget to lock the window and gave her the physical power and courage to climb down and flee. She felt very sad because she had left her daughter behind and feared for revenge from her partner. She said of the longings for her child: 'I was in fire. I didn't know what to do. I was in 
fire. But in my dream Mary brought me my child and I could hold Sara finally in my arms.' Through this dream, Mariella had empowered herself to fight, together with Mary, for her child. Mariella had obtained a devotional picture of Our Beloved Lady of Kevelaer, and she prayed silently while looking at the image that together with a burning candle functioned as her home altar. Before she had the picture, she prayed aloud because she was afraid that Mary would not be able to hear her. The previous summer she had gone to Kevelaer especially to ask Mary's active intervention in getting her child back, not only in her dreams but also in reality. Two weeks later the child was tracked down by the police and freed from her father's control. Since then, Mariella has thanked Mary daily for her help.

The other Muslim woman, Martina, a 38-year-old Russian refugee, told a similar story of assault, fear and loneliness. She said she felt intensely connected to Mary and that, since coming to Germany, Mary has meant everything to her. Martina considered herself a Muslim, but felt attracted to Catholic churches because, according to her, Mary's presence could be sensed there. At the same time she was afraid of being condemned by Mary because of her lesbian feelings. Although Mary had a central place in the life of Martina, she did not want people to see her engaging in any religious practice. Nevertheless, each morning she carefully selected religious items to carry around in her purse that day. On the day of the interview, these were two hand-copied Catholic prayers, an amulet her grandmother brought her from Mecca and a devotional picture of Mary. She considered the picture very special; to her it showed that Christianity and Islam were united, because underneath the image of Mary was written 'Fátima'. According to Martina, this showed that Mary and Fátima were the same person.

The stories of Mariella and Martina were similar to those of their nonMuslim fellow pilgrims, including a Protestant and a Buddhist woman, in that all wanted to be accompanied and helped by Mary in their experiences of violence or loneliness. Their relationship with Mary was a very personal one which should be researched further to understand how being traumatized influences women's very way of contacting and relating to Mary. The Protestant woman, for example, said she only prayed to Mary once after the pilgrimage because she feared becoming as dependent on Mary as on her perpetrator. These narratives and objects showed that shared feminine concerns for finding consolation through Mary for their sufferings were more important than religious differences.

\section{Fátima}

Fátima in central Portugal became a famous pilgrimage destination after three shepherd children had visions of the Virgin over the summer of 
1917. In 2006, an estimated 5 million people visited the shrine. The word Fátima evokes different associations for Christians and Muslims. For Christians it is the place in Portugal where Mary appeared. For Muslims the word evokes religious emotions in relation to Fatima (est. 605-633 AD) the daughter of Prophet Muhammad.

Desirée Vale spent three months at the site to study the views of both Christians and Muslims about the visiting of Muslims to the Virgin of Fátima (Vale, 2007). ${ }^{4}$ Although the majority of pilgrims to Fátima in Portugal are Catholic (85 percent) or other Christians, Vale found various sources that confirmed visits by Muslims. The Portuguese journal Sol gave a figure of 0.1 percent of the pilgrims being Muslim. The Muslim migrant population in Portugal is much smaller than in Germany and therefore Muslim pilgrims to Fátima tend to come from the Middle East, and are thus more likely to be visiting males or couples, than to be women living in the neighbourhood. According to the rector of the sanctuary, some years earlier there was a sudden interest from Iran, but this was due to the fact that the Muslims there thought that the sanctuary was dedicated to the daughter of Muhammad rather than to Mary.

One employee at the site clearly recalled the first Muslims she had met at the sanctuary shortly after she started to work there: 'It was a couple, both of them were teachers. They asked me all kind of things about the sacred place and were very much interested in its history. They told me that they came for "Maryam", that is Mary in Arabic.' She also remembered clearly a Turkish man aged 21 who lived in France. As a small boy, he had received an image of the Virgin of Fátima from his mother and since then he had wanted to come to the shrine. He called himself a Catholic Muslim. He wanted to know everything about the shrine and see everything. At the end of the day, he went back to her and said: 'I feel Mary in my heart, my dream has come true.'

Vale also spoke with a Turkish Muslim man. He told her that he was travelling around. When asked why he visited Fátima he said:

For Muslims, Mecca is the most important place, but I consider myself a tolerant person. I am Muslim, but not radical or fundamentalist. I respect all people, every religion and each nationality. I also believe in Jesus, Moses and Mary. They are holy people, also for me as a Muslim.

At Fátima, a discourse on tolerance and interfaith can also be occasionally heard from some Christians. The rector of the sanctuary wrote in the Daily Catholic (2003) that Fátima was a place where different religions could mix and in Fátima Luz e Paz (2006: Vol. 3, No. 11: 1), the site's quarterly newsletter, he said that the interest of non-Catholics in the site was rising and that it had therefore become an ecumenical meeting point. However, 
the idea that Fátima could become an interfaith shrine received much criticism from conservative Catholics. They complain about the insincerity of non-Catholic pilgrims and classify them as 'tourists'. When the rector was interviewed by Vale in 2007, he was more circumspect and said:

If they come individually, under their own authority and with devotion, I will say nothing about it. But if they come in groups it would be another story. Then we would have to find a way to receive them. With everything that we do in the domain of inter-religious relations, we have to be very wise and careful. The media are always interested in scandals.

In general, the more liberal voices in both religions, seeking common ground, refer to Mary as an important symbol they share. ${ }^{5}$

Opposite views to those of the aforementioned Muslim pilgrims are voiced by scripturalists who dominate Islamic websites. A question put on internet Islamic forums about what Muslims thought about visiting Catholic Marian shrines, led to the following answers:

Visiting Fátima in Portugal is shirk, ${ }^{6}$ idolatry, and absolutely forbidden in Islam.

In Islam it is forbidden to adore people, so there never can be a sanctuary outside the Ka'ba, the house of God in Mecca. Unfortunately there are still many misunderstandings between culture and religion. There are many people who do not know the difference, especially elderly and illiterate people follow old customs without knowing about it.

Another suggested:

There are many proofs in the Qur'an and the Sunna which forbid images. Because if that was not so, we would get the same situation as in Christianity, that is the adoration of the Cross, Mary and other statues. Result: the adoration of someone else than God. Further results: confusion.

Such reactions show that sharing a shrine with other religions is far from generally accepted.

\section{Meryemana}

The House of Mother Mary (Meryem Ana Evi in Turkish), near the town of Selçuk and the famous ruins of Ephesus in Turkey, has been an official Catholic pilgrimage site since 1892 . The origin story relates how a German Sister, Anne Catherine Emmerich, had visions of how St John had built a house for Mary in Ephesus where she spent the rest of her life. Although the majority of people visiting Meryemana are Christian 
tourists from the nearby seaside resorts of Kusadasi and Bodrum, Muslims regularly visit. On pictures of the site on the internet, one can see, among the scantily clad tourists, veiled Muslim women taking the healing water from the spring. ${ }^{7}$ Willy Jansen first visited the site in 1994, and returned in May 2007, when she interviewed six Muslims who regularly visited Meryemana about their reasons for doing so.

When Jansen asked Meral, a female silversmith in Selçuk, about Meryemana, she became very emotional. She said:

We go there regularly, and lots of Turkish people do. Especially the holy water is good. On 19 March 2000, my father had a heart attack. We went to get water from Meryemana and rubbed his heart with it. Since then he has completely recovered.

While she recounts this, her husband demonstrates by holding his hand on his heart. He confirms the story and continues: 'We respect Mary, and Jesus.' He points at the icon of Jesus above a row of brightly coloured water pipes. 'For us he is also a prophet. But we don't consider him a God like you do.' The large board near the door of their store exhibited the same mixture of cross-religious devotional objects as found in Martina's purse in Germany. Images of the Virgin hung alongside amulets bearing Allah's name. Some souvenirs combined the statue of the Virgin of Meryemana with the Islamic hand of Fatima.

'We respect her' is also the answer given by other respondents when asked about what they think of Mary. A restaurant owner, originating from Iran, said:

It is a beautiful walk of about nine kilometres from Selçuk to Meryemana. I have walked it at least nine times. I always take my friends there.

To the question whether these are friends from town he answers:

No, those all know it by themselves. But whenever I have visitors from Eastern Turkey or from Iran, I take them there. I must have been to the place at least three hundred times.

He knows that Mary is mentioned in the Qur'an, but cannot recite the verses: 'I am not that religious.'

A male tourist guide, who regularly goes to Meryemana, also did not want to be associated with scripturalist Islam and confessed that he was not a believer and does not know that much about the Qur'an: 'But my mother is. She regularly goes to pray at Meryemana. We respect her.' All the Turkish respondents talked very matter-of-factly about their respect for Mary and their visits to her shrine. 


\section{DISCUSSION}

\section{Religious Views on Marian Devotion and Practices of Unity}

Neither Mariella and Martina in Kevelaer nor Meral and the other Muslim respondents in Turkey or Portugal expressed any feelings of incongruity in showing respect for and asking for support from Mary. How can we explain this? Muslim familiarity with Mary, and the idea that she deserves respect, has to be placed in the context of Islamic theological doctrine on the subject. Mary, Mother of the Prophet Jesus, figures prominently in Islamic scriptures. Chapter 19 of the Qur'an is even titled 'Maryam' (the Islamic name for Mary), and contains several of the 70 verses in total that refer to her. The name Maryam is mentioned 34 times in the Qur'an (Stowasser, 1994: 67). The Qur'an extensively describes how the Lord helped Mary when she was in labour pains, by providing her with fresh dates and a cool spring, and many Muslim women recite these verses for heavenly support before or during labour. Mary also figures prominently in the Hadith, the accepted collection of stories about the acts and sayings of the Prophet Muhammad, that functions together with the Qur'an as the basis for Islamic belief and practice (Smith and Haddad, 1989: 162).

The attention to Mary in the Islamic sources is all the more remarkable given that, in the Christian New Testament, 'the Virgin is passed over almost in silence' (Warner, 1978: xxi). In effect, the Qur'an more clearly than the Bible formulates, through Mary, a whole range of virtues important to women. Mary's virtues are as much to be praised and followed as those of three famous Islamic women: Khadija, the first wife of the Prophet; Fatima, the daughter of the Prophet; and Aisha, the most beloved wife of the Prophet (Stowasser, 1994: 80). Foremost, Mary is seen as a virgin 'who kept her body pure' (S 66: 12). She was not touched by Satan at her birth like other children, and thus born without eternal sin (Gibb and Kramers, 1974: 329). Real women can never achieve this state of purity, but they can at least try to emulate her. Second, she is venerated for her piety and her obedience as a believer (Gibb and Kramers, 1974: 327; Lybarger, 2000). She is seen as a holy receptacle of the Prophet and thus of the divine word: 'Then we breathed into it from our spirit. She acknowledged the truth of the word of her Lord and of his book and she belonged to the obedient' (S 66: 12). Also in Sufism, Mary is seen as a symbol of the kind of spiritual receptiveness that is needed to receive divine inspiration (Schimmel, 1975: 429). This scriptural attention to Mary has certainly influenced popular devotion as well as provided an imposing gender script for women.

Mary shows many similarities to Fatima, the daughter of the Prophet, and is at times conflated with her. The veneration for Fatima is especially observable among Shi'ites in Iran and Iraq. Shi'ite traditions herald Fatima as the 'queen of the women of paradise, next Maryam' (Gibb and 
Kramers, 1974: 101) or place her above Mary as one of her names is 'Maryam al-Kubra', the greater Mary. Both women are central figures that represent purity, piety, compassion and righteous suffering. Both are therefore associated with light. They are both considered as Mother of the Faith. Their maternal role as mothers of martyrs enables them to mediate between their sacred male relatives and common believers. Despite having borne children, both have received the enigmatic epithet 'virgin' (Gibb and Kramers, 1974: 101). Similar cults of devotion have developed around each of them, although these are rejected in other branches of Christianity and Islam (Bill and Williams, 2002). Although Martina in Kevelaer was probably unaware of all this, she had also conflated Mary and Fatima. She found proof in the prayer card with the image of Mary and the word 'Fátima' underneath. For her, this resolved any contradictions between the two religions and showed their unity. Similarly, the French-Turkish visitor to Fátima had been inspired by the same image. The conflation of Mary and Fatima in objects and names in everyday life makes it more comprehensible that Muslims should chose to visit the Lady of Fátima.

Despite the extensive presence of Mary in the Islamic sources, none of our respondents mentioned the Qur'an or the Hadith in justifying their religious behaviour. Both in Germany and in Turkey, several Muslim pilgrims even explicitly distanced themselves from those other Muslims who only look at the scriptures. Scripturalist voices in Islam that denounce the veneration of saints, because they see it as polytheism and idolatry, are gaining force, and our search on the internet forums showed that they actively make themselves heard through this new medium. In their fear that such religious crossovers will challenge Islamic identity, they paradoxically ignore the Qur'anic texts about Mary and her being a model for believers. In this they resemble the Christian opponents to interfaith shrines who ignore the deep-felt religious respect for Mary held by Muslims.

Contrary to the preaching of difference, stands the unity practised by the Muslims interviewed. None of the Muslim pilgrims were actively involved in interfaith dialogue with fellow pilgrims but, in their practices, several bridges to Christianity can be seen. Apart from the respect for Mary, a recurring feature is the transmission of information on Mother Mary by their mothers. The devotion to Mary reconfirmed ties with their own mothers as well as with the supernatural Mother. In this, Muslim devotees parallel Catholic pilgrims whose relatedness to Mary reflects their relatedness to their own mother and other family members (Hermkens, Jansen and Notermans, forthcoming). Unity can also be seen in their prayers in search of consolation and help with physical, social and psychological problems. The comfort they derived from sharing their problems with Mary led them to disregard theological admonitions not to pray to someone other than God. This behaviour is similar to that of many 
Catholic pilgrims. Unity was further expressed in the narratives of themselves as tolerant persons, respectful of other religions and of the mother of another prophet, and in the handling of religious objects that were allowed the same interfaith space. In their rituals, prayers, narratives and objects, these pilgrims expressed a similarity in religious feelings and perceptions that is being denied in other discourses.

\section{Gender and Sharing Shrines}

An analysis of all the cases investigated shows that both male and female Muslims visit Marian sites but that they give different reasons for doing so and that, as among Catholics, women take the lead. What does this mean in terms of gender relations?

The reasons mentioned in the literature for the attractiveness of Marian pilgrimages for Christian women also seem to apply to the Muslim women with whom we spoke. The first concerns the sense of shared womanhood with Mary. While church and secular authorities may stress Mary's virginity and purity, women who visit her shrines often talk about Mary as a mother who suffered herself, and of her power to ease their suffering as women and mothers. None of the men said that they had gone to seek healing and consolation.

A second reason is Mary's relative closeness, both socially and spatially. Mary is deemed to be closer to people, more of a mediator between themselves and the distant and judging God, like a mother who mediates in real life between the child and the father. Mary's femininity makes her nearer and more approachable, especially during intimate moments such as childbirth. Many of Mary's sanctuaries are also physically close to their adherents. After buying a devotional picture in Kevelaer, Mariella took Mary into her home so that she would always hear her. The Turkish woman Meral could have gone on a pilgrimage to Mecca and brought water from the spring of Zemzem, which is also attributed with healing and purifying qualities, but this is far more costly and time-consuming than using Mary's spring at walking distance at Meryemana.

A third reason is that women do not only go for themselves but also for their relatives. Women tend to feel more responsible for the direct physical, moral and social well-being of their family and seek supernatural support in carrying out this role. Mariella in Germany went to pray for her child still in the hands of her violent husband and Meral in Turkey went for her father. Of the male visitors interviewed, only Meral's husband expressed some familial preoccupations, by confirming his wife's story. The other men tended to go more out of curiosity, for recreation or to relive memories of their youth. Several authors have noted before that women's religious practices can be characterized as caring for others and that women's requests for spiritual and supernatural care are an extension 
of their socially assigned roles as caretakers of the family (e.g. Dubisch, 1995; Mernissi, 1977).

A fourth reason is that women find in Mary a feminine role model to emulate, but in a far more complex way than is often presented. The respondents did not say they went to Mary to be like her, but they nevertheless saw her as a model of a powerful woman who could and did help them in times of distress. Associating with her enabled them to escape from a violent partner, to assist sick family members, or to face loneliness and a hostile society. In attributing power, courage and authority to Mary, women constructed a more complex, multifaceted image of Mary than the virtuous, obedient and sacrificial female servant to God as upheld by both the Catholic Church and the Qur'an. And, by strengthening Mary, they strengthened themselves.

Another reason that more women than men are attracted to Marian sanctuaries is that these provide opportunities for forms and themes of expression that are often classified as feminine, and also enable women to circumvent religious authority (Gemzöe, 2000; Gemzöe, forthcoming; Mernissi, 1977). Certain practices and demeanours common in religious behaviour - bending the head, bowing, casting one's eyes down, immobilization - that express the submission of humans to the supernatural, are also upheld as ideal feminine behaviours both in Christianity and Islam. This can be seen in the way the Catholic Church has influenced representations of Mary, limiting these to either the devoted mother or the demure Virgin. Fragility, submission and pure femininity are upheld in millions of Lourdes statuettes all over the globe and form the basis of many examples for women on how to pray and hold their bodies. More powerful images of Mary, such as images showing Mary curing the ill or blessing monks with milk from her breast, or as the autonomously sovereign Mother of Mercy, were banned or not approved by the Catholic Church (Warner, 1978: 328). Similarly, in Islam, the gestures of religious submission are reflected in the ideal behaviour of women. The promotional image for the Iranian film Maryam Muqaddas (Saint Mary) depicted Mary as a modestly veiled young woman, eyes downcast and head bent forward. Women at the studied pilgrimage sites clearly found it relatively easy to perform gestures of submission, while the men more often stood apart. In such acts, women not only reproduce gender ideals, they can also subvert them by taking this appropriate feminine behaviour to extremes and thus challenge the religious and gender hierarchy. In Fátima, it is mostly women who progress, in a painful and sacrificial way, on their knees across the square in front of the Chapel of Apparitions to fulfil their vows. Church officials do not encourage such overtly submissive behaviour and would prefer it if the devotees followed more orthodox rituals such as attending Mass. Gemzöe (forthcoming) argues that women's insistence on performing these acts is not only an act of defiance 
in the face of masculine priestly authority, but also a route to religious authority by finding direct ways to the supernatural without requiring mediation by men. By denying women's religious acts, religious authorities denigrate women. But, by their own practices, women modify and alleviate their subordination to religious authority. The vilified acts are mobilized and redirected by women for their own ends.

How can we assess Marian devotion from a feminist perspective? Some feminists have unmasked Marian symbolism as a cultural script that helps force women into a virtuous, sacrificial and devoted way of life. The orthodox Catholic discourse on Mary has been analysed as repressive in relation to women's rights (see, for example, Margry, 2004; Warner, 1978). Other feminist theorists, however, have pointed out that Mary can be attributed with other meanings, such as that of a powerful woman, able to control and destroy evil - as in the text of Mary Magnificat. They argue that Mary can be, and should be, seen as a symbol for the religious empowerment of women and the Marian pilgrimage as a form of opposition to the doctrines of the Church (Halkes, 1980; Spretnak, 2004). Alternatively, they argue that women feel empowered through their faith (Rodriguez, 1994), or they see use of feminine symbols as 'a form of release from or mediation of patriarchal cultural orders' (Taylor, 2004: 17).

How do our pilgrims fit this discussion? In their narratives, it was not Mary's obedience or virtuousness that came to the fore, but her power. A power that can overrule parental power or lead the devotee out of a hellish situation (Mariella), that can console and offer company (Martina), that can heal (Meral) or make one's dreams come true (Turkish man in Fátima). The women, and also the men visiting Mary have stressed, each in their own way, Mary's abilities to exert power rather than her virtuousness or demure comportment. The ambiguous character of the symbol of Mary offers space for personal interpretation. Moreover, most found that praying or making a pilgrimage enabled them to take a better hold of their lives, to make their own marriage choice, to find strength in fleeing a violent partner, in facing loneliness or finding a cure for an ill father. Within the limits set by their circumstances, they felt empowered as individuals but also to some extent as women.

Yet, despite the agency evidenced by Muslim pilgrims in appropriating Marian symbolism for their personal use, and their subsequent feelings of being strengthened, one may question the effects on changing structural inequalities. This was most clearly exemplified by the Protestant woman in Germany who said that she stopped praying to Mary because she feared becoming trapped in yet another dependent relationship. The respondents that came from a shelter for battered women did not ask Mary's help to change violent gender relations but to flee and hide from their personal persecutors. And Martina did not question the heteronormativity embodied in Mary but felt ashamed about her lesbian feelings. 


\section{CONCLUSION}

The preceding discussion has shown that the multivalent symbol of Mary can not only divide Christians and Muslims, but also bring them together in shared practices, values and beliefs. An analysis of the Marian devotion of a number of Muslims who visited sites in Germany, Portugal and Turkey has shown that Muslims partake in Marian pilgrimages for similar reasons to Christians. Building on theological sources, they interpret the symbol of Mary in their own way, and seek the Virgin's help in their own sorrows and insecurities and, in so doing, build on the memory of their own mothers. Their acts are private acts. Unlike the ideologues on the internet, they do not participate in a public debate on how Mary should be seen or approached, or in a discourse on 'proper' Islamic or Catholic identity. The Muslim visitors to Marian shrines do not do so to openly challenge Islamic doctrines but to seek healing, comfort or distraction. Their personal experiences seem separated from the wider religious-political context. Nevertheless, even if they do not make the connection themselves, their ritual behaviour, narratives and use of objects can be explained as a form of integration and as a rejection of Muslim-Christian antagonisms.

The data gathered also showed the genderedness of this practice: in the preference for a female saint, in the numerical dominance of women, in the search for the healing of feminine worries about relatives, childbirth or domestic violence, or in the quest for female empowerment, Mary is linked to women and competing constructions of femininity. What this genderedness means for men and masculinities could be the subject of future research. St Mary conforms to Islamic norms of true femininity, including the veil, modesty, piety and obedience, but, at the same time, can empower those who lack power. For the pilgrims, this aspect of personal empowerment dominates. Structural inequalities, however, are hardly challenged. Marian devotion should therefore not be seen either as totally repressive or as fully empowering. The denigration of pilgrimage as a folk religion or a women's practice reflects patriarchal fears for the ways women appropriate it as a way of ignoring or resisting existing hierarchies in religion and gender. Women's actual religious behaviour at shared shrines complicates and challenges the dominant discourses of mutual incompatibility and irredeemable opposition between religions and genders.

\section{NOTES}

1. For example, the conference 'Anthropological Approaches to the Study of Shared Sacred Places and Mixed Pilgrimages in the Mediterranean', Paris, 24-25 March 2006. 
2. This research is linked to the NWO (Netherlands Organization of Scientific Research) programme 'The Power of Pilgrimage: A Comparative Study' and the NORFACE (New Opportunities for Research Funding Agency Cooperation in Europe) programme 'Gender, Nation and Religious Diversity in Force at European Pilgrimage Sites'. We gratefully acknowledge the support of NWO and NORFACE for part of this research.

3. de.wikipedia.org/wiki/Kevelaer\#Entwicklung_der_Prozessionen_und_ Pilgerzahlen (accessed 15 June 2007).

4. We kindly thank D. Vale for allowing us to use her data.

5. See, for example, www.islamfortoday.com/galvan03.htm, www.cfpeople. org/FrRay/Mary2002a.htm and www.crossroad.to/Quotes/spirituality/ mary-worship.htm (accessed 15 June 2007).

6. The word shirk refers both to polytheism, the forbidden act of ascribing associates to God, and to idolatry, the veneration of material idols as God.

7. See, for example, the photographs by John Kulick on www.quovadimus. org/turkey99/misc/10-400.html (accessed 10 May 2007). See also www.meryemana.net.

\section{REFERENCES}

Albera, D. (2005) 'La Vierge et l'islam. Mélange de civilisations en Méditerranée', Le Débat 137: 134-44.

Bill, J. and J.A. Williams (2002) Roman Catholics and Shi'i Muslims: Prayer, Passion and Politics. Chapel Hill: University of North Carolina Press.

Coleman, J. and J. Eade, eds (2004) Reframing Pilgrimage: Cultures in Motion. London: Routledge.

Coleman, S. and J. Elsner, eds (2002) Pilgrim Voices: Narrative and Authorship in Christian Pilgrimage. New York: Berghahn Books.

Daily Catholic (2003) 'Fátima to Become Interfaith Shrine', 11 January; at: www.dailycatholic.org.no110803.htm (accessed 8 November 2006).

Dubisch, J. (1995) In a Different Place: Pilgrimage, Gender, and Politics at a Greek Island Shrine. Princeton, NJ: Princeton University Press.

Duijzings, G. (1991) 'Van het recht pad geraakt. Gezamenlijke pelgrimages van moslims en christenen in Joegoslavië en Albanië', pp. 113-26 in W. Jansen (ed.) Lokale islam. Geloof en ritueel in Noord-Afrika en Iran. Muiderberg: Coutinho.

Eade, J. and M. Sallnow, eds (1991) Contesting the Sacred: The Anthropology of Pilgrimage. London: Routledge.

Gemzöe, L. (2000) Feminine Matters: Women's Religious Practices in a Portuguese Town. Berlin: Walter de Gruyter.

Gemzöe, L. (forthcoming) 'Caring for Others: Mary, Death and the Feminization of Religion in Portugal', in A.K. Hermkens, W. Jansen and C. Notermans (eds) Moved by Mary: The Power of Pilgrimage in the Modern World. Aldershot: Ashgate.

Gibb, H.A.R. and J.H. Kramers (1974) 'Fatima'; 'Maryam', pp. 101 and 327-30 in Shorter Encyclopaedia of Islam. Leiden: E.J. Brill.

Halkes, C.J.M. (1980) Met Myriam is het begonnen. Opstandige vrouwen op zoek naar hun geloof. Kampen: Kok.

Hermkens, A.K., W. Jansen and C. Notermans, eds (forthcoming) Moved by Mary: The Power of Pilgrimage in the Modern World. Aldershot: Ashgate.

Jansen, W. (2005) 'Visions of Mary in the Middle East: Gender and the Power of a Symbol', pp. 137-54 in I.M. Okkenhaug and I. Flaskerud (eds) Gender, 
Religion and Change in the Middle East: Two Hundred Years of History. Oxford: Berg.

Jansen, W. and H. de Jonge, eds (1991) Islamitische pelgrimstochten. Muiderberg: Coutinho.

Kühl, M. (2007) 'Met Maria in het vuur van geweld. Mariadevotie in een blijf-vanmijn-lijfhuis', Raffia 19(4): 9-11.

Lybarger, L.D. (2000) 'Gender and Prophetic Authority in the Qur'anic Story of Maryam: A Literary Approach', The Journal of Religion 80(2): 240-70.

Margry, P.J. (2004) 'Global Network of Divergent Marian Devotion', pp. 98-102 in C. Partridge (ed.) Encyclopedia of New Religions: New Religious Movements, Sects and Alternative Spiritualities. Oxford: Lion Publishing.

Mernissi, F. (1977) 'Women, Saints, and Sanctuaries', Signs 3(1): 101-12.

Nolan, M.L. and S. Nolan, eds (1989) Christian Pilgrimage in Modern Western Europe. Chapel Hill: University of North Carolina Press.

Reader, I. (2007) 'Pilgrimage Growth in the Modern World: Meanings and Implications', Religion 27(3): 210-29.

Reysoo, F. (1991) Pèlerinages au Maroc: Fête, politique et échange dans l'Islam populaire. Neuchâtel: Institut d'Ethnologie.

Rodriguez, J. (1994) Our Lady of Guadalupe: Faith and Empowerment among MexicanAmerican Women. Austin: University of Texas Press.

Schimmel, A. (1975) Mystical Dimensions of Islam. Chapel Hill: University of North Carolina Press.

Schleifer, A. (1997) Mary the Blessed Virgin of Islam. Louisville, KY: Fons Vitae.

Smith, J.I. and Y. Haddad (1989) 'The Virgin Mary in Islamic Tradition and Commentary', The Muslim World 79(3-4): 161-87.

Spretnak, C. (2004) Missing Mary: The Queen of Heaven and Her Re-emergence in the Modern Church. New York: Palgrave Macmillan.

Stowasser, B.F. (1994) Women in the Qur'an, Traditions, and Interpretation. Oxford: Oxford University Press.

Tapper, N. (1990) 'Ziyaret: Gender, Movement, and Exchange in a Turkish Community', pp. 236-55 in D.F. Eickelman and J. Piscatori (eds) Muslim Travellers: Pilgrimage, Migration, and the Religious Imagination. London: Routledge.

Taylor, P. (2004) Goddess on the Rise: Pilgrimage and Popular Religion in Vietnam. Honolulu: University of Hawaii Press.

Vale, D. (2007) 'Moslims naar "het altaar van de wereld". Competing discourses op het Portugese heiligdom van Fátima', unpublished MA thesis, Radboud Universiteit Nijmegen.

Warner, M. (1978) Alone of All Her Sex: The Myth and the Cult of the Virgin Mary. London: Quartet Books.

Willy Jansen is professor of gender studies at the Radboud University Nijmegen. She has published widely on gender, education and religion in the Middle East and North Africa. Address: Institute for Gender Studies, Radboud University Nijmegen, Thomas van Aquinostraat 2, PO Box 9104, 6500 HK Nijmegen, Netherlands. [email:w.jansen@maw.ru.nl] 
Meike Kühl is a research master student in gender studies at Utrecht University. Her research interests are gender, violence, survivorship and religion. She has done fieldwork in Iran, Germany and the Netherlands. Address: Gender Studies Department, Attn Meike Kühl, Kromme Nieuwegracht 29, 3512 HD Utrecht, The Netherlands. [email:m.kuhl@students.uu.nl] 